\title{
The Buddha Remains: Heritage Transactions in Taxila, Pakistan
}

\section{Hassan Asif and Trinidad Rico}

\begin{abstract}
This chapter offers a perspective from ethnographic heritage research on the preservation of Buddhist artifacts in the Muslim community of Taxila, Pakistan. While this form of heritage preservation practice and art may be interpreted as paradoxical, we discuss social, institutional, and political factors that are responsible for the revival and continuation of these heritage practices. Through the examination of this case study, we discuss a unique mode of engaging with the negotiation of past and present spiritual identities that resists the assumption that this is a territory of heritage in conflict.
\end{abstract}

Keywords Pre-Islamic - vernacularization · art · ethnographic heritage · Pakistan

\section{SEARCHING FOR THE BUdDHAS}

The traveler going from Islamabad toward Taxila can notice that the road is marked by numerous workshops and display centers showcasing items such as stone vases, lamps, tiles, and other decorative objects: Taxila is

H. Asif $(\bowtie)$

UNESCO Pakistan, Islamabad, Pakistan

T. Rico

Rutgers University, New Brunswick, New Jersey, USA

(C) The Author(s) 2017

T. Rico (ed.), The Making of Islamic Heritage, Heritage Studies in the

Muslim World, DOI 10.1007/978-981-10-4071-9_7 
famous in Pakistan for its traditional stone craft industry. These objects are decorated using geometric or floral patterns with little or no use of anthropomorphic or zoomorphic iconographic elements, something that may be expected in this Muslim region. However, what is not seen in these displays are the Buddhist statues that the very same stone-sculptors of Taxila are also creating. This relatively hidden practice is well known in local circles and owes its continuing existence to Taxila's history as an important Buddhist center. As a secret practice, to find an artisan who is willing to display the "Buddhist side" of his craft is a challenging task.

Earning the trust and gaining access to the experience of artisans who engage in the making of Buddhist statues in this unlikely contemporary context is a process that suggests this may be a case study in dissonant heritage and the challenges involved in its preservation. However, as this chapter argues, the experience and modes of engagement of these Muslim artisans with the creation of non-Muslim heritage objects suggests a more nuanced subaltern construction of these heritage practices that is created in association with and through mediation of specific social milieus and opportunities.

This discussion begins just off the main road to the Taxila Museum, where a street spirals through the village of Khan Babar and leads to an abandoned train station. From there, Raheem took convoluting turns into other smaller alleys to finally stop in front of a house with a small gate. ${ }^{1} \mathrm{He}$ passed through the gate and entered a courtyard in which there were a few chairs, a coffee table, and a pedestal fan. There was nothing out of the ordinary in this courtyard except for a number of miniature yet conspicuous Buddha statuettes standing on a small table by the fan. Over the course of this first meeting, Raheem unveiled Buddha statues of all sizes from behind plant pots in the courtyard, from inside cabinets, and from storage boxes (Fig. 7.1). Raheem is a practicing Muslim who makes stone sculptures of the Buddha for a living. Although he is a master sculptor, he does not openly display or talk about his skills. Like most sculptors in Taxila, Raheem inherited the craft from his forefathers. In the early twentieth century, Raheem's grandfather worked as a contractual laborer for British archaeologists in Taxila. That is when his grandfather was first exposed to the Gandharan Buddhist sculptures. Being a stonemason, he soon realized the economic potential of this craft when he witnessed the extent to which British archeologists valued the excavated sculptures. In his time off, he practiced making sculptures with Gandharan characteristics using the local green schist stone. Raheem asserted that this is when the 


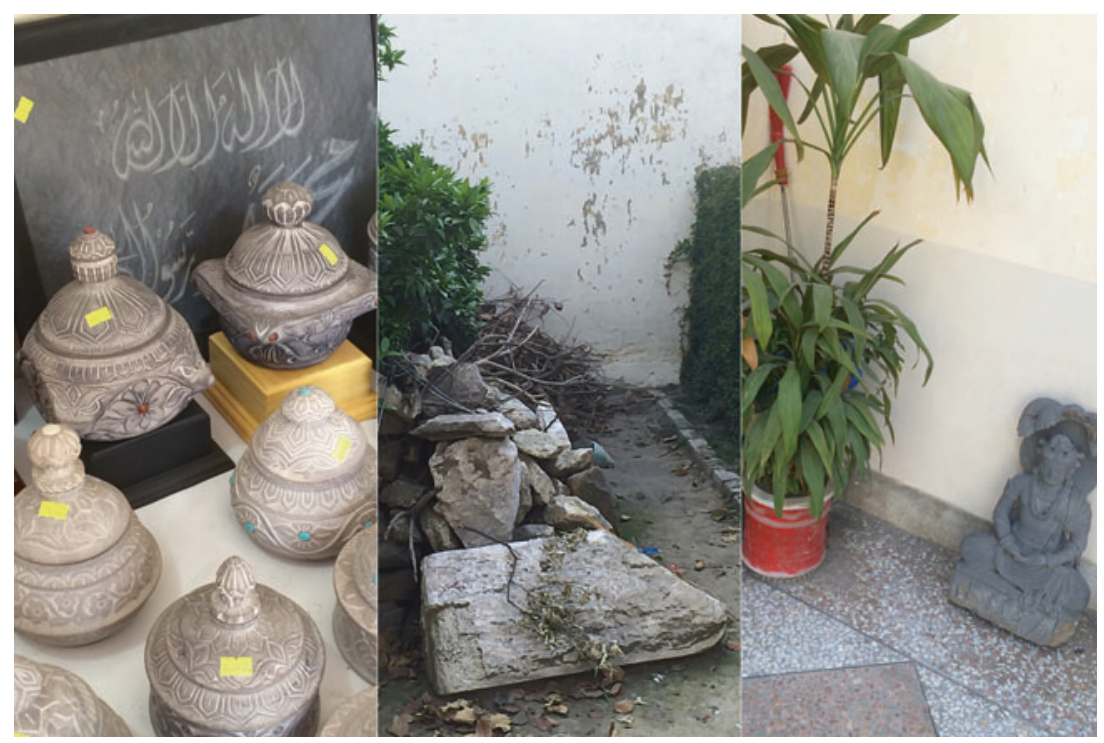

Fig. 7.1 Buddhist relic caskets placed in front of Islamic calligraphy with "Allah" inscribed on the stone (left); schist stone lying by the gate of Raheem's house (center); Buddha sculpture in the bodhisattva stage, unveiled from behind a plant pot (right) (Photographs by Hassan Asif, 2014)

Gandharan Buddhist sculpture was revived in Taxila after hundreds of years. Raheem's father then learnt the craft after witnessing the high price paid for his own father's works. He quit his job to focus solely on making these replicas.

Taxila is and was during this period a predominantly Muslim community in a predominantly Muslim state. There is, therefore, an expectation of conflict in reference to how Muslim Taxila perceives the construction and circulation of sculptures of the Buddha, and by association, about the artisans who have to negotiate their craft between their private spaces and their public life. To fully appreciate these tensions requires an understanding of the place of Islam in this specific context and how it is associated with particular preconceptions with regards to artistic values in the realm of the arts in Pakistan. On the one hand, the parameters of what constitutes authorized art have been dominated by discussions of the relative tolerance of idolatry (De Glopper 2014 on intermediary traders and antique runners; 
Elias 2012; Noyes 2013). A relevant reflection in this discussion is the fate of the Bamiyan Buddhas in 2001, destroyed by the Afghan Taliban in accordance with ultraconservative Salafist precepts (Hussain 2015). Less well publicized is the similar case of the Jahanabad Buddha located in Swat, Pakistan (Rose 2007)—believed to be the largest rock carving of the Buddha in the world (Khaliq 2016) - whose face was dynamited by the Pakistani Taliban in 2007. These are the issues that immediately spring to mind when we consider the construction and stewardship of Buddha statues by Muslims in contemporary times. On the other hand, local response in Pakistan toward this type of reaction to Buddhist imagery has been polarized. Officially, the Pakistani government condemned the attack, with then President Pervez Musharraf sending Lieutenant Moinuddin Haider to prevent the destruction through persuasion (Zaeef 2011). The public reaction was varied: some supported the Taliban's action and rationale of erasing "false idols" from the land, along with ratifying Mullah Omer's statement that "all we are breaking are stones" (Stone and Farchakh Bajjaly 2008, 93); others, especially the literati, mourned the collective loss suffered by humankind (Hussain 2015).

This chapter considers how the creation of Buddha statues in this specific Muslim contemporary context can be understood to reflect two worldviews: a dominant heritage approach focusing on identifying and managing any conflict of values, and an ethnographic approach that reveals individual negotiations of public and private lives on the part of the artisans themselves. Therefore, this discussion will highlight the existence of Buddha statues in Taxila as a reality that reflects the operation of two ontologies: first, a negotiation of values that juxtapose debates in Islam about representational art and heritage practices that attempt to mediate different sets of coexisting values, and second, the practices and attitudes to the construction of Buddhist art from the perspective of artists like Raheem. The latter emphasizes the significance and contribution of ethnographic approaches to the study of heritage value, in particular as a strategy for avoiding essentialized and decontextualized appraisals of any iteration of Islamic values in situ.

\section{Representational Art in Heritage Practices of Taxila}

It has been extensively argued that heritage values always operate on multiple conflicting planes, which despite potentially insurmountable differences, can and should be managed to reach consensus and enable preservation (Kang 2009; Nagaoka 2011; Van Der Valk 2014). Though 
the challenges faced by such an approach have been oversimplified, it nevertheless remains central to how events, such as the Taliban's destruction of the Bamiyan Buddhas, are discussed in heritage debates. A notable feature of this type of analysis is the legitimization and hierarchization of certain forms of heritage value ascribed by particular institutions over other values. In this sense, forms of expertise that engage in this work of mediation are in a position to potentially create a conflict between values that may otherwise be stratified and amalgamated in more productive ways. This chapter suggest, therefore, that we need to consider a correlation between the production of conflicting heritage values and the practice of expert and institutional heritage preservation, where one ontology has to give way for the other one to be realized. As it has been argued that heritage preservation as a practice is in itself destructive of other forms of engagement with material culture (Karlström 2005; Layton et al. 2001), we consider that heritage concerns as an ontology may be incompatible with understanding ways in which artisans like Raheem negotiate their own lifeworlds. In addition, the creation of Buddha statues is entangled with a vernacular heritage discourse in which economic, institutional, and ideological subjectivities are intertwined.

However, because of the dominant concern with destruction in heritage preservation as a field (Rico 2016), entanglements of Buddhist heritage value in Muslim contexts have been mostly articulated in terms of concerns with iconoclasm. The destruction of the Bamiyan Buddhas has been used as a defining case study in heritage to characterize the problem of attitudes to idolatry in Islamic contexts and has included concerns with international law (Francioni and Lenzerini 2003; Mani 2001) and with the localized construction of such art in the Bamiyan valley (Dupree 2002; Levi 1972; Reza 2012). When detached from these dominant heritage debates, the relationship between Buddhist representational art and Islamic contexts takes a different tone. This relationship has shifted significantly in accordance to changing attitudes through time (Elias 2012), variations from individual to individual (Flood 2002), and changes in political regimes (Elias 2007; Flood 2002), in such a way that a consistent universal attitude to this type of representation cannot be concluded.

In addition to necessary considerations of the spiritual context in which the Taxila Buddha statues exist, economic transactions of these artistic objects as they are currently being circulated in Taxila have to be examined. The locally crafted sculptures of the Buddha in Pakistan are part of a commercial market that is implicated in their conception and continuous 
survival in what could be an ideologically averse milieu. The story of the origins of Buddha sculptures as an art form that has become part of the heritage of Taxila is an oddity. The preservation of this art form through the discovery, revival, and valorization of Buddha sculptures illustrates that heritage can be preserved without any direct interference on the part of institutional actors and influences, and even in spite of it. The historical context in which the Buddha sculptures were incorporated into the heritage assemblage of Taxila informs the complex contemporary state of preservation and the actors involved in it. Around 200 BC, during the time of the Indian emperor, Ashoka, Taxila was known as Taksasila-the "City of Cut Stone." Taksasila developed into an important hub for education, where local Buddhist devotees applied their stone-cutting and carving skills to make the very first anthropomorphic representations of the Buddha (Khan and Hassan 2003). This was the origin of the stonecarving industry.

Modifications in the sculptures produced were a reflection of the history of Taxila and the various rulers that came to govern it. For instance, after the collapse of the Mauryan Empire, the Buddha sculptures produced in Taxila increasingly incorporated various Greek aesthetic influences from the incoming Greco-Bactrian Empire (Dani 1986). This tradition continued until the invasion of the White Huns around $450 \mathrm{AD}$, when the carvings ceased to be made. It was not until the nineteenth century - when the British administrators of colonial India had Alexander Cunningham carry out archeological excavations, unearthing sculptures from the Gandharan period near the city of Peshawar (Marshall 1951) - that the ancient Gandharan art of Buddha sculpting was revived by the very same stone sculptors in Taxila who had witnessed the resurfacing of this object as part of a coherent archaeological culture. Today, this art form survives in the region's characteristic Gandharan-inspired secular decorative art. Although the Buddhist stone craft industry is flourishing, it does so clandestinely.

The involvement of international agencies charged with the upkeep of Taxila's heritage "authenticity" further obscures the status of Raheem's craft. Since Pakistan's independence in 1947, the federal Archaeology Department has been a steward of preservation for Gandharan art in Pakistan. Pakistan's state-level experimentation with various versions of national identity based on Islam has tended to put these newly formed heritage identities as a Muslim nation in opposition to the ancient preIslamic identity of the region. For instance, the pre-Islamic past of the 
region was sidelined for more "Muslim values" by various governments, and especially military dictatorships such as Zia ul Haq's regime in the 1970s, and this was followed by an ardent policy of Islamization in Pakistan (Devji 2013). Meanwhile, in other areas of Taxila, archaeological sites are still being excavated, producing more evidence of this historical period and its survival in the archaeological record. Some of these discoveries formed the basis for the inclusion of Taxila as a World Heritage Site in 1980 by the United Nations Educational, Scientific, and Cultural Organization (UNESCO). Raheem uses the same criteria to describe the significance of his craft by drawing on UNESCO's rhetoric of a universal significance ascribed to Taxila. However, the emphasis within these criteria on a particular definition of what constitutes authenticity entangles his craft with economic networks of transaction. This entails two types of transactions: Raheem's sculptures are simultaneously considered to be authentic and forged. By UNESCO's standards, the replicas that he produces are not "authentic." However, as they enter a process of becoming forgeries, they are made authentic and fall under the protection of the 1970 Convention. A smuggling mafia is involved in this market, made favorable by the need for sustenance by the artisans who create them. As a result of this complex relationship with contrasting forms of authenticity, the heritage value that has developed around this art form involves diverse forms of "expertise," all of which exclude and even silence the artisans themselves (c.f. De Cesari 2010; Smith 2006). It is in this context that this chapter brings forth the voice of Raheem and other locals engaged in the Gandharan art industry as stone sculptors and artisans, during the summer of 2015.

\section{The Artisans of Taxila}

"The Buddha is even mentioned in the Holy Qur'an," explained Raheem upon being asked why he was engaged in the production of these statues, suggesting an immediate understanding of the contradiction that was apparent between his spiritual affiliation and the product of his work. Raheem is a humble and highly respected artisan in the networks of the Buddhist craft and has acquired over 30 years of experience. Simultaneous with his defense of the craft, he clarified, "I think Buddhist art and making such art is completely forbidden according to Islamic law. We cannot even say but in this case." But Raheem's paradoxical statements can be better understood in consideration of the context in which the notion of heritage 
is negotiated in Taxila, through the rhetoric and practices that define heritage locally, and in line with the economic, institutional, and ideological frameworks that inform it.

It is important to point out that the Buddha sculptures in Taxila are neither being used for ritual purposes nor owned by Buddhists within Pakistan, so their heritage value is a negotiation between potential and actual value, not simply as a negotiation that takes place in a pluralistic society but also within the same person. This challenging perspective considers the intricate nuances between diametrically opposed cultural signifiers that are usually presented as binaries, such as the "Muslim versus Hindu" and "Muslim versus Buddhist" dichotomies that are pertinent to the Indian subcontinent. Values attributed to these objects therefore need to be considered in complex shifting contexts-where do the Buddha statues go when they leave Raheem's workshop? They need to reach their designated destination, be that a Buddhist devotee buyer abroad or the mafia network that operates in Taxila. Failing this, they risk exposing Raheem, his craft, and the location where the statues are produced. Raheem must take care not to leave any evidence, such as schist stone lying in front or near his house, which could result in social ostracizing on account of the local mobilization of certain Islamic values, as discussed earlier. He keeps all of his schist stones in his small garden, guarded from the unfavorable context outside.

At first, these locally made replicas were not sold abroad, but a foreign market emerged about 50 years ago when individuals from countries like Japan and South Korea became interested in Gandharan aesthetics. Since Raheem became established as an artisan, however, he has witnessed a decrease in local interest for these sculptures as well as a decline in the amount of foreign sales owing to persisting security issues in Pakistan. Aware that a demand for these sculptures continues to exist abroad, the artists have therefore explored other avenues to reach their customers. Consequently, the way in which these objects move from the workshop to the buyer has undergone enormous transformation. It now involves a mafia network that aids the smuggling of these replicas out of Pakistan-an unlikely steward of preservation for objects that seems to be strategically deployed as both art and heritage, though not to the artisan's advantage. Due to the current economic pressures and a dearth in local buyers, Raheem expressed hesitation at whether he would pass this skill onto his children.

The mafia actors entered the network of production as a response to local legislation and international conventions that hindered the transport 
of these replicas abroad. Government officials use the 1975 Antiquity Act to harass artisans, and there are reports that state that officials have often attempted to extort money from artisans in return for allowing them to continue making the statues. As a result, Raheem, like others, limits his public exposure. Section 25 of the Act forbids dealing in antiquities unless the artisans obtain a license from the Director General of Archaeology (The Antiquities Act 1975). Over the course of his career, Raheem has tried to obtain this license to export antiquities (available under Form "D" of the 1975 Act) without success. A closer examination of this issue with key stakeholders at the Taxila Museum and the Punjab Small Industries Corporation (PSIC) - a government initiative with the slogan, "Caring for the heritage"-confirmed that in practice this license does not exist. In addition, sections 15-17 of the 1969 Customs Act also prohibit the transport of valuable antiquities (The Customs Act 1969). Despite the fact that Raheem's art is not "antique," these clauses nonetheless affect his work and business model. The smuggling mafia, by virtue of its role as an intermediary in the construction of the statues' value, is a catalyst for the value transformation of statues from "replica" to "antique." 2 According to Raheem, the physical "antique-making process" involves the application of a paste made from mixing liquor together with chuna (calcium carbonate) powder and a powder from an older kanjoos (black earth from ancient sites), after which the statue is buried underground for a few days for it to acquire the look and feel of an antique. Raheem, now an accomplice in the deceitful collapse of historical authenticity, expressed immense confidence in this technique, claiming that no laboratory in the world could detect the counterfeit. His art, perhaps intrinsically contested in value, assumes extrinsic heritage value far from the privacy of his workshop. However, the sculpture's true value lies in its ability to sustain the artisan. As long as it provides this, Raheem can reconcile the rest.

Like Raheem, Saqib, a fellow sculptor, now works exclusively on commissioned orders. Saqib expressed his intention to leave the craft altogether due to a lack of profit and close his shop, "Gandharan Art," located in the government-funded artisan village at Lok Virsa Museum in Islamabad. This is one of the few initiatives taken by the Pakistani government to make these artists visible. Though they are both sculptors, Saqib and Raheem have selected different business models for their livelihood: While Raheem relies on the smuggling mafia to sell his sculptures, Saqib sells his Buddhist relic caskets in the commercial market. Unlike Raheem, Saqib is able to sell his work on the open market due to the lack of 
anthropomorphism in the relic caskets. As a result, he is able to strip the caskets of any Buddhist/non-Islamic values as might be perceived by the casual local Muslim shop visitor. He chooses to decorate the relic caskets with floral patterns of the lotus flower, which is iconic in Buddhism. Another important point is that while Saqib does make Buddha sculptures, he does not sell them in his shop for fear of offending local Muslim visitors. He has a table in his shop where he works on the relic caskets. $\mathrm{He}$ does this openly without any fear of offending locals, because as long as he is not making anthropomorphic representations, he can publicly engage in this craft. Interestingly, he also makes Islamic art using Gandharan stone, such as decorative tiles with Islamic calligraphy. This is perhaps one of the ways in which he can subvert any conflict in values and continue practicing his craft via appropriation of icons and symbols that are relevant to (and at the same time placate) the Muslim public sphere in which he operates.

Conflicts over the heritage values bestowed upon these art forms are also exacerbated through institutional practices. A conversation with Farooq Ali, Managing Director of PSIC, revealed a specific PSIC initiative for the revival of Taxila stone art. Interestingly, he confessed that during initial planning he had made it clear that they would not "deal with this side [Buddhist art] of Taxila sculptures because of the complexities." This can be understood as a subtle move to encourage artisans to consider creating more marketable items. Instead, PSIC is mainly focusing on developing tiles and other utensils for use in the garden or as materials for construction. But one has to wonder what other institutional mechanisms or lack thereof allow the craft to flourish or perish. Widespread, institutionalized corruption in local governments-largely considered a result of the recent devolution of administrative responsibilities from federal to provincial levels - further obscures the role of institutional machineries responsible for the preservation of heritage in Taxila (Gould et al. 2013). The expectation that this creates, from the perspective of artisans such as Raheem, is that the instruments of government are working intentionally against their work. The ambiguity surrounding the question of whether this craft is legal or not itself complements the ancillary systematic corruption that allows for the mafia to smuggle artifacts out of the country. This also perhaps refocuses the tensions surrounding the Buddha statues of Taxila away from more familiar public debates over the relative place of non-Muslim representational art in Taxila's heritage assemblages. 


\section{Discussion ANd Conclusion}

Given his engagement with the black market for antiques and its inherent dangers, Raheem keeps to himself. However, and perhaps surprisingly, he remains undeterred, deferring to the blessings of God as the instrument that helps him overcome all the perils of his craft. Returning to the question that motivated this research, one of the expressed justifications for participating in this craft that recurred in various conversations with Taxila artisans was the recognition of Buddha as a saint. By citing a contested reference about the Buddha in the Quran, ${ }^{3}$ they dilute any dissonance of their work, as the Buddha is justified by the verse: "No community but that a warner (prophet) has passed in it" (Quran: 35:24). Some, of course, reject this view based on the argument that Buddhists are not part of Abl al-Kitab (People of The Book; Tabrizi 2012). Nonetheless, the uncertainty provoked by the appeal to this Qur'anic verse is instrumental in two ways. First, as long as there is ambiguity over the Buddha's status in Islam, the production of Buddhist sculptures can evade socioreligious censure in a context where other representational art-such as Hindu iconographic art-is rarely tolerated. Second, the artisans deploy a carefully crafted discourse to navigate the traditions of Islam and Buddhism strategically. Saqib justified his participation in the craft precisely in this manner, explaining, "If you look at the character of the Buddha, he was a saint like our saints and should be revered instead of being shunned." Such a rhetorical strategy is used by the artisans to nullify any internal conflict involved in crafting idols while remaining followers of Islam. Ultimately, these sets of verbal justifications also aid the artisans as they parse through other ideologically tumultuous terrains.

For instance, at the time of fieldwork, Raheem was working on replicating a Greco-Bactrian plate depicting a homosexual act. While explaining the narrative of this plate, Raheem acknowledged, "Muslims do not believe in this and some even shun it." He then added, "We have no interest in the story; our job is just limited to the scope of art and to just carve out the story from stone." There is a similar method of ideological regulation in operation extending beyond the private toward the public ideological practices of Taxila artisans. Raheem explained that religious locals taunt and threaten him to stop creating sculptures of the Buddha, but he responds, "If I am doing the sin, why are you bothered? And if there is any sin in this [making sculptures], then I will be held responsible not you. But also remember that 
the One [God] above is so great and forgiving that there are no limits for that. I am just working through His favor and He is helping me throughout." Not only does Raheem evince an internal logic to his practice but also a hierarchy of ideological nominal structures that can be employed with flexibility according to social context. The rhetoric the artisans use in the privacy of their artistic engagements deploys the Buddha's appearance in the Quran in order to placate their individual anxieties. However, they remain aware that a mobilization of this association could prove inadequate when faced with the Muslim public sphere. In this context, the artisans do not frame the sculpture as the entity of concern, but rather, their craft. They equate the abstract principles of the craft with the elusive nature of the Islamic God (see also discussions in George 2010).

In conclusion, the conflict concerning the Buddha sculptures of Taxila is not what it first appears to be. A form of conflict between the artisan's private practice and the public sphere is both inevitable and necessary for the continued existence of the Taxila sculptures. This chapter has suggested that what is needed in order to characterize Taxila's heritage is a more nuanced understanding of the economic, institutional, and ideological practices of those involved in the construction of this art form embedded with heritage value. In proposing this, we seek to problematize the idea that heritage value can simply be bestowed on suitable objects through the examination of local agency, independently of global "patterns of exclusion and symbolic meanings" attached to heritage constructs (Bianchi and Boniface 2002). Rather than addressing the relative merit of "pluralism," this type of enquiry places the emphasis and exercise of hierarchy making on non-institutional actors, and considers the negligence and complicity of the state in the construction and the failure of preservation efforts throughout.

\section{Notes}

1. Due to the ambiguous and contested public perception of the work of Taxila, we have chosen to anonymize the real names and locations of the artisans throughout this chapter.

2. For more information on intermediary traders and antique runners see, for instance, Jerome Levi, "Commoditizing the Vessels of Identity: Transnational Trade and the Reconstruction of Rarámuri Ethnicity" and Christopher Steiner, "African Art in Transit."

3. The contested reference is usually sourced in the identification of the Prophet Dhu'l Kifl (Al Anbiya 85 and Sad 48). 


\section{BIBLIOGRAPHY}

1969. "The Customs Act 1969." Karachi Chamber of Commerce and Industry Accessed June 15, 2016. https://kcci.com.pk/Rnd/Tax\%20Docs/Pakistan\% 20Customs\%20Act\%201969,\%20updated\%2030\%20June\%202015.pdf.

1975. "The Antiquities Act 1975." International Union for Conservation of Nature (IUCN) Accessed June 15, 2016. http://cmsdata.iucn.org/down loads/antiquities_act_1975.pdf.

Bianchi, Raoul, and Priscilla Boniface 2002. "Editorial: The Politics of World Heritage." International Journal of Heritage Studies no. 8 (2): 79-80.

Dani, A. H. 1986. The Historic City of Taxila. Tokyo: Centre for East Asian Cultural Studies.

De Cesari, Chiara. 2010. "World Heritage and Mosaic Universalism: A View from Palestine." Journal of Social Archaeology no. 10 (3): 299-324.

De Glopper, Charlotte. 2014. "Review of The Politics of Iconoclasm: Religion, Violence and the Culture of Image-Breaking in Christianity and Islam." Politics, Religion and Ideology no. 15 (3): 479-480.

Devji, F. 2013. Muslim Zion: Pakistan as a Political Idea. Routledge.

Dupree, Nancy Hatch. 2002. "Cultural Heritage and National Identity in Afghanistan." Third World Quarterly no. 23 (5): 977-989.

Elias, Jamal J. 2007. “(Un)making Idolatry: From Mecca to Bamiyan.” Future Anterior: Journal of Historic Preservation, History, Theory, and Criticism no. 4 (2): 12-29.

Elias, Jamal J. 2012. Aisha's Cushion: Religious Art, Perception, and Practice in Islam. Cambridge, MA: Harvard University Press.

Flood, Finbarr B. 2002. "Between Cult and Culture: Bamiyan, Islamic Iconoclasm, and the Museum." The Art Bulletin no. 84 (4): 641-659.

Francioni, Francesco, and Federico Lenzerini 2003. "The Destruction of the Buddhas of Bamiyan and International Law." European Journal of International Law no. 14 (4): 619-651.

George, Kenneth M. 2010. Picturing Islam: Art and Ethics in a Muslim Lifeworld. Malden, MA: Wiley-Blackwell.

Gould, William, Taylor C. Sherman, and Sarah Ansari 2013. "The Flux of the Matter: Loyalty, Corruption and the 'Everyday State' in the Post-Partition Government Services of India and Pakistan.” Past and Present no. 219 (1): 237-279.

Hussain, Zahid. 2015. "Destruction of the Past.” DAWN Accessed May 25, 2016. http://www.dawn.com/news/1168714.

Kang, Xiaofei. 2009. "Two Temples, Three Religions, and a Tourist Attraction." Modern China no. 35 (3): 227-255.

Karlström, Anna. 2005. "Spiritual Materiality: Heritage Preservation in a Buddhist World?” Journal of Social Archaeology no. 5 (3): 338-355. 
Khaliq, Fazal. 2016. “Abandoned Heritage: In Jahanabad, World's Biggest Buddha Sculpture Awaits Tourists." The Express Tribune Accessed May 15. http://tribune.com.pk/story/349610/abandoned-heritage-in-jahanabadworlds-biggest-buddha-sculpture-awaits-tourists /.

Khan, Ashraf, and Mahmood Hassan 2003. "Buddhism and Its Influence on the Cultural Heritage of Pakistan with Special Emphasis on Gandhara." Journal of Asian Civilizations no. XXXI (1): 55-59.

Layton, Robert, Peter G. Stone, and Julian Thomas eds. 2001. Destruction and Conservation of Cultural Property. London: Routledge.

Levi, Jerome M. 1992. "Commoditizing the Vessels of Identity: Transnational Trade and the Reconstruction of Rarámuri Ethnicity." Museum Anthropology no. 16 (3): 7-24.

Levi, Peter. 1972. The Light Garden of the Angel King: Journeys in Afghanistan. London: HarperCollins Publishers.

Mani, V.S. 2001. "Bamiyan Buddhas and International Law." The Hindu: Online Edition of India's National Newspaper Accessed 21 May. http://www.the hindu.com/2001/03/06/stories/05062523.htm.

Marshall, John. 1951. Taxila: An Illustrated Account of Archaeological Excavations Carried Out at Taxila Under the Orders of the Government of India Between the Years 1913 and 1934. Cambridge: England University Press.

Nagaoka, Masanori. 2011. "Buffering Borobudur for Socio-economic Development: An Approach Away from European Values-Based Heritage Management." Journal of Cultural Heritage Management and Sustainable Development no. 5 (2): 130-150.

Noyes, James. 2013. The Politics of Iconoclasm: Religion, Violence, and the Culture of Image-Breaking in Christianity and Islam. New York: I.B. Tauris.

Reza, Said. 2012. "Destruction of Bamiyan Buddhas: Taliban Iconoclasm and Hazara Response." Himalayan and Central Asian Studies no. 16 (2): 15-50.

Rico, Trinidad. 2016. Constructing Destruction: Heritage Narratives in the Tsunami City. London: Routledge.

Rose, Mark. 2007. "Pakistan's Heritage at Risk.” Archaeology-A Publication of the Archaeological Institute of America Accessed May 25, 2016. http:// archive.archaeology.org/online/features/pakistan/.

Smith, Laurajane. 2006. Uses of Heritage. London and New York: Routledge.

Stone, Peter G., and Joanne Farchakh Bajjaly eds. 2008. The Destruction of Cultural Heritage in Iraq. Woodbridge, Suffolk, UK: The Boydell Press.

Tabrizi, Taymaz G. 2012. "Ritual Purity and Buddhists in Modern Twelver Shi'a Exegesis and Law." Journal of Shi'a Islamic Studies no. 5 (4): 455-471.

Van Der Valk, Arnold. 2014. "Preservation and Development: The Cultural Landscape and Heritage Paradox in the Netherlands." Landscape Research no. 39 (2): 158-173.

Zaeef, Abdul Salam. 2011. My Life with the Taliban. 1 ed. London: Hurst. 
Hassan Asif is a consultant for UNESCO Pakistan. He earned his MA in Museum and Gallery Practice at UCL Qatar and currently conducts research on the role of UNESCO as mediator of different cultural and spiritual values in contemporary and historical heritage projects in Pakistan.

Trinidad Rico is assistant professor and director of the Cultural Heritage and Preservation Studies program at Rutgers University, USA. Her work focuses on ethnographic heritage studies, risk and disaster, cosmopolitanism, and expertise with particular emphasis on the broader Muslim world. She is founding editor of the Pivot series Heritage Studies in the Muslim World (Palgrave Macmillan).

Open Access This book is licensed under the terms of the Creative Commons Attribution 4.0 International License (http://creativecommons.org/licenses/ by $/ 4.0 /)$, which permits use, sharing, adaptation, distribution and reproduction in any medium or format, as long as you give appropriate credit to the original author(s) and the source, provide a link to the Creative Commons license and indicate if changes were made.

The images or other third party material in this chapter are included in the chapter's Creative Commons license, unless indicated otherwise in a credit line to the material. If material is not included in the chapter's Creative Commons license and your intended use is not permitted by statutory regulation or exceeds the permitted use, you will need to obtain permission directly from the copyright holder.

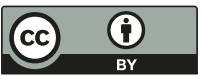

